Kuznetsova $S$.

Doctor of Science (Economics), Professor Academician of the Academy of Economic Sciences of Ukraine Professor of the Department of Accounting and Auditing Banking University (Kyiv),Ukraine; e-mail: kuznet@meta.ua

Krzikallová K. Doctor of Philosophy Associate Professor of the Department Accounting and Taxation $V \check{S} B$ - Technical University of Ostrava, Czech Republic; e-mail:katerina.krzikallova@vsb.cz

Kuznetsov A.

Doctor of Philosophy, (Economics) Doctorant of the Department of International Finance, Accounting and Taxation Alfred Nobel University Dnipro,Ukraine; e-mail: kuznetsov77@ukr.net

\title{
PERFORMANCE INDICATORS FOR MANAGEMENT CONTROL OF DIRECT TAXES: EVIDENCES FROM THE CZECH REPUBLIC AND UKRAINE
}

Abstract. Methodological principles of constructing a set of performance management indicators proved in order to build block of management control of direct taxes. Groups of indicators suggested depending on the influence of the environment and character of measurement. Using correlation - regression analysis trends and comparative assessment built for financial and non-financial performance management indicators of direct taxes for companies in the Czech Republic and Ukraine. The results of the research focused on comparison of selected indicators of taxation and related aspects in the Ukraine and the Czech Republic shows that most of the trends can be evaluated as a positive.

Keywords: direct taxes, management control system (MCS), taxation, performance management, quantitative analysis

JEL classification: H21, M41

Formulas: 1; fig.: 9, tabl.: 2, bibl.: 29

Кузнецова С.

д.е.н., професор, Академік Академії економічних наук Украӥни, професор кафедри бухгалтерського обліку і аудиту

Державний вищий навчальний заклад «Університет банківської справи» Київ,

Україна; e-mail: kuznet@meta.ua

Кржикаллова К.

доктор філософії, дочент кафедри бухгалтерського обліку і оподаткування

$V \check{S} B$ - Технічний університет Острави,

Чеська Республіка; e-mail: katerina.krzikallova@vsb.cz

Кузнецов $A$.

к.е.н., докторант кафедри міжнародних фінансів,

бухгалтерського обліку та оподаткування

Університет Альфреда Нобеля, Дніпро,

Україна; e-mail: kuznetsov77@ukr.net

\section{ПОКАЗНИКИ ЕФЕКТИВНОСТІ ДЛЯ УПРАВЛІНСЬКОГО КОНТРОЛЮ ПРЯМИХ ПОДАТКІВ: ДОКАЗИ 3 ЧЕХІЇ ТА УКРАЇНИ}

Анотація. В статті обгрунтовано методологічні засади побудови комплексу показників вимірювання ефективності 3 метою побудови підсистеми управлінського контролю прямих податків. Запропоновано групи показників в залежності від впливу 
середовища та характеру вимірювання. 3 використанням кореляційно - регресійного аналізу побудовано тренди та порівняльні оцінки для фінансових та нефінансових показників ефективності прямих податків для компаній Чеської республіки та України.

Ключові слова: прямі податки, система управлінського контролю, оподаткування, управління ефективністю, кількісний аналіз

Формул: 1; рис.: 9; табл.: 2; бібл.: 29

Кузнецова С.

д.э.н., профессор, Академик Академии экономических наук Украины, профессор кафедры бухгалтерского учета и аудита, Государственное высшее учебное заведение «Университет банковского дела»,Киев, Украина; e-mail:kuznet@meta.ua

Кржикаллова К. доктор философии, доиент кафедры бухгалтерского учета и налогообложения, $V \check{S} B$ - Технический университет Остравы Острава, Чешская Республика; e-mail:katerina.krzikallova@vsb.cz Кузнецов $A$. к.э.н., докторант кафедры международных финансов, бухгалтерского учета и налогообложения Университет Альфреда Нобеля, Днепр, Украина; e-mail:kuznetsov77@ukr.net

\section{ПОКАЗАТЕЛИ ЭФФЕКТИВНОСТИ ДЛЯ УПРАВЛЕНЧЕСКОГО КОНТРОЛЯ ПРЯМЫХ НАЛОГОВ: ДОКАЗАТЕЛЬСТВА ИЗ ЧЕХИИ И УКРАИНЫ}

Аннотация. В статье обоснованы методологические положения построения комплекса показателей измерения эффективности с целью построения подсистемы управленческого контроля прямых налогов. Предложены группы показателей в зависимости от воздействия среды и характера измерения. С использованием корреляционно регрессионного анализа построены тренды и сравнительные оценки для финансовых и нефинансовых показателей эффективности прямых налогов для компаний Чешской республики и Украины.

Ключевые слова: прямые налоги, система управленческого контроля, налогообложения, управления эффективностью, количественный анализ

Формул: 1; рис.: 9; табл.: 2; библ.: 29

Introduction. This traditional approach is to consider taxes as the payment obligation that the state defines by law for the payment of public needs through public budgets. In the past two decades, this approach is enhanced development institute of social responsibility in society. Direct taxation is still a very topical question taking into account on the one hand the needs of governments and on the other hand the obligations companies. Both the mentioned groups have opposite targets. The governments need to levy maximum sum of taxes to obtain enough sources for their spending. The corporations and individuals mostly try to do their best to optimize their tax liability to have more free private sources.

A company ought of course to be profitable on the on hand and to have effective level of direct taxes on the other hand. It requires checking on taxability. Management of direct taxes calls for the preparation of forecasting of 'taxability' and taxation. MCS must be able to produce information about 'taxability' of company. In case of direct taxes it is necessary to compare actual financial results and direct tax burden. The central research questions are: a) whether the company has made a profit or a loss on its ordinary activities? b) By how much this year's direct taxes is bigger or smaller than last year's direct taxes? c) By how much this year's direct taxes, particularly corporate income tax, are bigger or smaller than last year's direct taxes in comparison with changes in a profit? 
Literature review and the problem statement. Tax is in terminology defined as an obligatory payment that is in accordance with law levied to the individuals or companies by the government [1]. In this sense Ulbrich underlined [2] that taxes belong to the major revenue sources of governments that enable to fund their activities. The importance of fiscal policy, especially taxation and its influence on the planning of firms have been already surveyed by old famous authors of the economics $[3,4,5,6,7,8,9,10]$, e.g. Hansen [5] pointed out that the theory of planning by firms is much more complicated than that of household planning because firms have a much larger number of action parameters. Trabandt \& Uhlig [9] studied how Laffer curves differ across countries in the United States and the EU-14. They found out that labor income and consumption taxes are important for accounting for most of the cross-country differences. They calculated the implications for the long-term sustainability of current debt levels by calculating the maximal permanently sustainable interest rate. According to their study the introduction of human capital has important effects for the labor income tax Laffer curve across countries as well as the sustainable interest rate. Otherwise, the aim of the mentioned groups is similar, the maximizing the profits of the firms and maximizing of their standard in case of the household.

The traditional point of view to division of taxes is classification to direct and indirect taxes. Nevertheless, it can meet with the terms taxes on income and taxes on consumption. In the first case, the subject of direct taxes is the income or property of the taxpayer. The taxpayer is usually obliged to calculate and pay his tax liability by himself. On the contrary, Široký, Strrílková, Krajňák underlined [12] that the indirect taxes are payed by the final consumer in the price of purchased goods and services.

The direct taxes can be further divided into taxes on income and on the property. The very relevant requirement to the tax system is its economic efficiency. With represent taxation as instrument of economic policy, a large part of literature is concerned with the measurement of the effective level of taxes for companies [13, 14, 15, 16, 17, 18] using ETR, the book effective tax rate of the firm, as the dependent variable. Due to the economically efficient tax system, especially in case of corporate income taxation, the business decisions are not affected by international differences in CIT rates and ways of CIT tax bases treatment [19]. According to some researchers $[20,21,22,23,24]$ the problem is that each country in the world wants to maintain their sovereignty in the field of income tax rules.

To extend the body of literature on connection between fiscal policy and MCS, we specifically address this gap by taking up a research question which focuses on how effective level of direct taxes could be maintained through implementation special indicators to measure performance in direct taxation for companies. This study deals explicitly with the techniques, model and indicators of direct taxes management control system contrary to management team expectation according to the company's strategy.

Research results. Various techniques could be used to assist with measurement aspects of direct taxes management. This process aims to provide quantitative analysis within management control of direct taxes context. It is includes estimate based on time series (histogram), correlationregression analysis, extrapolation, methods of data collection.

Methodology for measurement of performance indicators for management control of direct taxes includes 3 steps showed on the Figure 1.

Step 1 Determine set of performance indicators for management control of direct taxes. It is necessary to establish a general relationship between the profits and CIT. Financial performance indicators (FPIs) provide quantitative measures for management control of direct taxes. It is important taking into account that the monetary amounts stated are only given meaning in relation to other financial items. That means using compare techniques. As yard-stick could be used following figures: taxable income, expenses and revenue; the trend over time (for instance, this year/lust year); the direct taxes of other business and industry; the standards in country; the economy in general; future potential. 


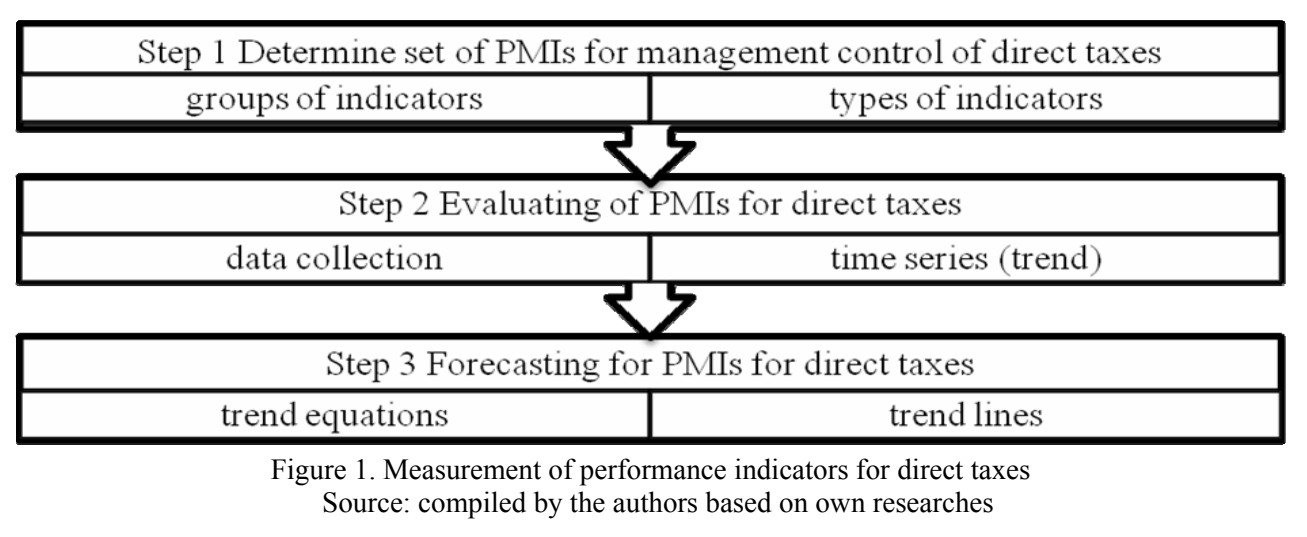

Non - finance performance indicators (NFPIs) for direct taxes could include external and internal groups of indicators. In this case external indicators describe macroeconomic items of taxation characterized by qualitative measure of taxpayer satisfaction in different countries. There has been a growing emphasis on NFPIs for direct taxes for a number of reasons, such as: concentration on too few variables, lack of information on quality of direct taxation for business, changes in structure of direct taxes, focus on long-term perspective, changes in environment (political, social, economic, IT), changes in business environment.

Figure 2 shows groups and types PMIs.

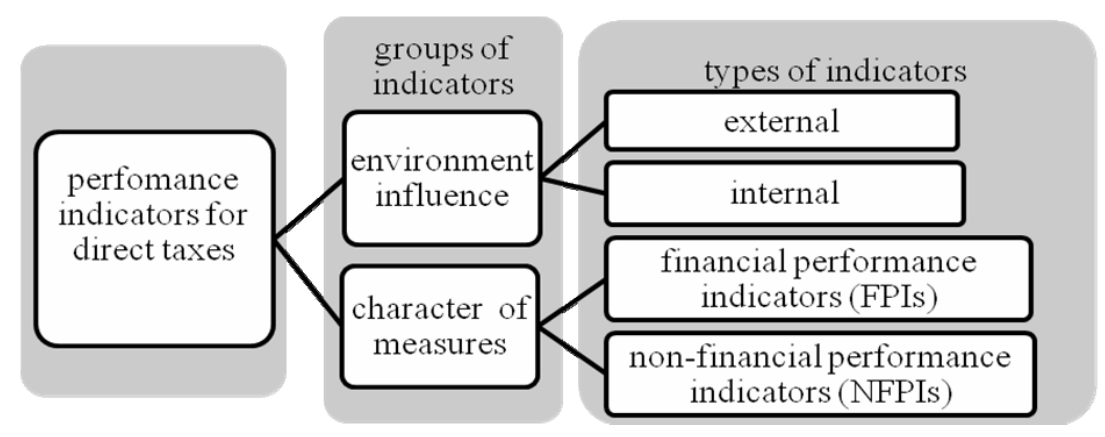

Figure 2. Performance indicators for management control of direct taxes Source: compiled by the authors based on own researches

Summarizing information from international open official databases let selected range of external NFPIs for direct taxes: tax payments by business; time to prepare and pay taxes, number of visits or required meetings with tax officials, firms expected to give gifts.

Key indicators may be represented by initial indicators, which should be divided into two groups: external and internal performance indicators.

The external indicators should be classified those allowing to estimate the 'taxability' for company depending on changes in external factors such as inflation, GDP, profitability in the industry. Relative to direct taxes advisable to analyze changes in the amount of direct taxes compared to the inflation index, in\% of GDP. Accordingly this evaluation allows to measure external influence on the management of direct taxes.

Internal ainancial performance indicators (FPIs) should be directed to measure the performance of the management of direct taxes in relation to the internal environment. Therefore, these indicators can determine the the efficiency the internal management system. Local financial performance are considered from the perspective of general results. This allows making judgments about the general trends in the position compliance with strategy.

Step 3 Forecasting for PMIs for direct taxes. Linear correlation- regression analyses is the statistical method of estimating using historical data from a number of previous periods.

A linear relationship can be expressed in the form of equation which has the common form $y=a+b x(1)$, where $y$ is the dependent variable, depending for its value on the $x ; x$ is the 
independent variable, whose value helps to determine the value of $y$; $a$ is a constant, fixed amount; $\mathrm{b}$ is a constant, being the coefficient of $\mathrm{x}$ (that means, that the number by which the value of $\mathrm{x}$ should be multiplied to determine the value of $y$ ).

Management have to either be confident that conditions which have existed in the past will continue into the future or amend the estimates of figures (performance indicators) by the linear correlation-regression analysis to allow for expected changes in the future. It is essential to analyze the effectiveness of the company not only to find out why it is high or low, or better or worse than last year. Taxability must be analyzed in more detail using secondary ratios. These coefficients allow us to understand the correlation and regression interrelationships between external and internal factors determining the current situation in the company.

Tax payments by businesses are calculated by World Bank as the total number of taxes paid by businesses, including electronic filing. The tax is counted as paid once a year even if payments are more frequent. The Figure 3 shows changes in tax payments for the Czech Republic and Ukraine over the last 10 years.

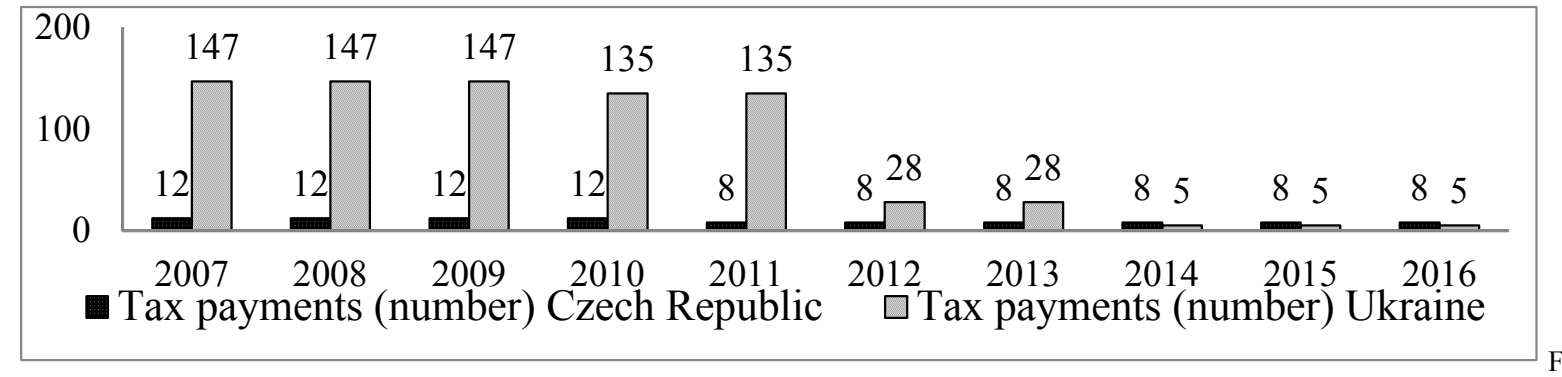

igure 3. Tax payments: the Czech Republic and Ukraine Source: compiled by the authors based on [25]

The most significant feature is that tax payments have declined dramatically in Ukraine since 2012. By contrast, the number of tax payments in the Czech Republic is more lower (12 between 2007-2010). In the following five years, the Czech Republic number fluctuated around the 8 mark, while Ukrainian number reduced steeply. Ukrainian figures tumbled to 5 numbers in 2014, and the Czech Republic tax payments plunged to 8 in 2011. From 2014 onwards, there was a leveling out in both countries.

The Figure 4 illustrates changes in the amount of hours to prepare and pay taxes for the tax payers between 2007 and 2016, in the Czech Republic and Ukraine.

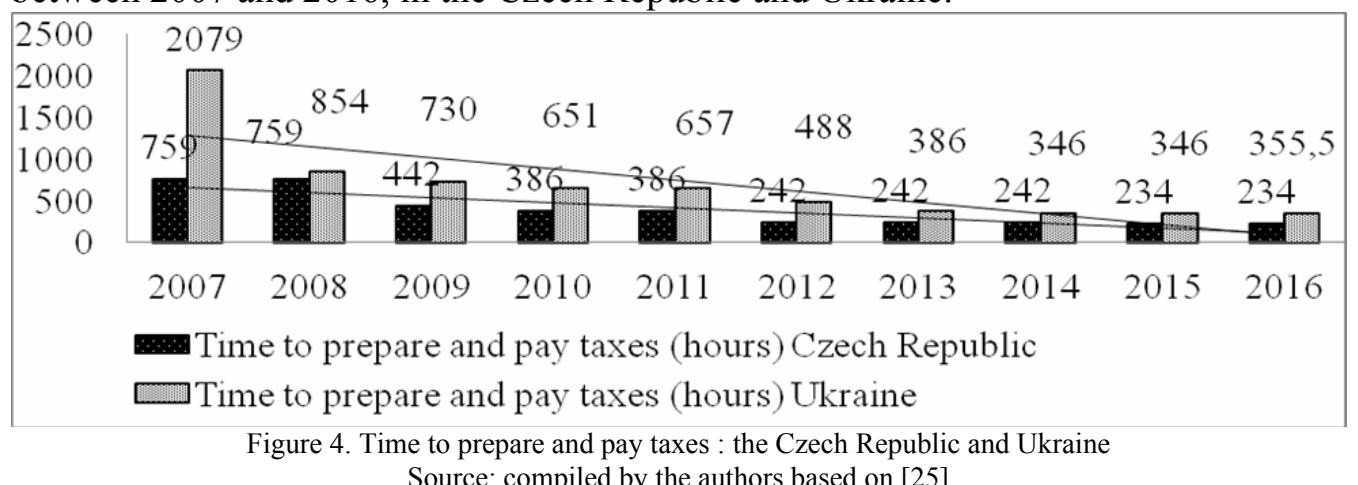

The time to prepare and pay taxes for Ukraine dropped sharply from 2079 hours in 2007 to 355.5 hours in 2016, decreasing more than five times. The biggest decrease was in 2008, when it jumped almost by four, from 2079 hours to 854 hours. The other trend in the graph is the decline in time to prepare and pay taxes for the Czech Republic. Although hours to prepare and pay taxes in the Czech Republic are lower, it echoes Ukraine figures, declining at the approximately same rate. From 2009 onwards, there was a sudden decline in both countries. Between 2012 and 2016, the Czech Republic hours averaged between 242 and 234 hours per year, while Ukrainian time 
fluctuated between 488 and 355.5 hours. In general, time to prepare and pay taxes for both the Czech Republic and Ukraine have declined dramatically since their peak in 2007.

In the set of external FPIs for direct taxes could be included: share of direct taxes in total amount of taxes; direct taxes (\% of GDP); percentage of taxes on income, profits, and capital gains in total taxes; Corporate income tax (\% of GDP); Corporate income tax as \% of total taxation; Personal income taxes as \% of GDP; Personal income taxes as \% of total taxation.

The Table 1 summaries information about direct taxes indicators for the Czech Republic and Ukraine by selecting and reporting the main features to make comparisons where relevant.

The Figure 5 gives information about share of direct taxes in total amount of taxes in the Czech Republic and Ukraine from 2010 to 2014.

Is it can be seen from the graph, there were substantial differences in the proportion for these countries. On average, $50 \%$ of all taxes, comprising five years, were direct taxes in Ukraine. However, it consists of only $20 \%$ for the Czech Republic respectively. The trend line for this country is directed to maintain common trend, while the trend line for Ukraine demonstrate trend to decrease.

Table 1

Direct taxes performance indicators: the Czech Republic and Ukraine

\begin{tabular}{|c|c|c|c|c|c|c|c|c|c|c|c|}
\hline \multirow{2}{*}{ Indicators } & \multirow{2}{*}{$\begin{array}{l}\text { Country } \\
\text { Name }\end{array}$} & \multicolumn{10}{|c|}{ period } \\
\hline & & 2007 & 2008 & 2009 & 2010 & 2011 & 2012 & 2013 & 2014 & 2015 & 2016 \\
\hline \multirow{2}{*}{$\begin{array}{l}\text { Direct taxes as } \\
\% \text { of total } \\
\text { taxation }\end{array}$} & $\begin{array}{l}\text { Czech } \\
\text { Republic }\end{array}$ & .. & .. & .. & 20,4 & 20,3 & 19,9 & 20,2 & 21,2 & .. & .. \\
\hline & Ukraine & .. & .. &.. & 50,4 & 47,5 & 47,2 & 49,6 & 46,5 & 43,0 & 43,3 \\
\hline \multirow{2}{*}{$\begin{array}{l}\text { Direct taxes as } \\
\% \text { of GDP }\end{array}$} & $\begin{array}{l}\text { Czech } \\
\text { Republic }\end{array}$ & .. &.. &.. & 6,6 & 6,8 & 6,8 & 7,0 & 7,2 & .. & .. \\
\hline & Ukraine &.. & .. &.. & 11,6 & 12,2 & 12,1 & 12,1 & 10,8 & 11,0 & 11,5 \\
\hline \multirow{2}{*}{$\begin{array}{l}\text { Corporate } \\
\text { income tax as \% } \\
\text { of GDP }\end{array}$} & $\begin{array}{l}\text { Czech } \\
\text { Republic }\end{array}$ & 4,5 & 4,0 & 3,4 & 3,2 & 3,2 & 3,2 & 3,3 & 3,4 &.. & .. \\
\hline & Ukraine &.. &.. &.. & 3,7 & 4,2 & 4,0 & 3,8 & 2,5 & 2,0 & 2,2 \\
\hline \multirow{2}{*}{$\begin{array}{l}\text { Corporate } \\
\text { income tax as \% } \\
\text { of total taxation }\end{array}$} & $\begin{array}{l}\text { Czech } \\
\text { Republic }\end{array}$ & 13,0 & 12,2 & 10,5 & 9,9 & 9,5 & 9,2 & 9,3 & 9,9 & .. &.. \\
\hline & Ukraine &.. &.. & .. & 16,2 & 16,5 & 15,5 & 15,5 & 10,9 & 7,7 & 8,3 \\
\hline
\end{tabular}

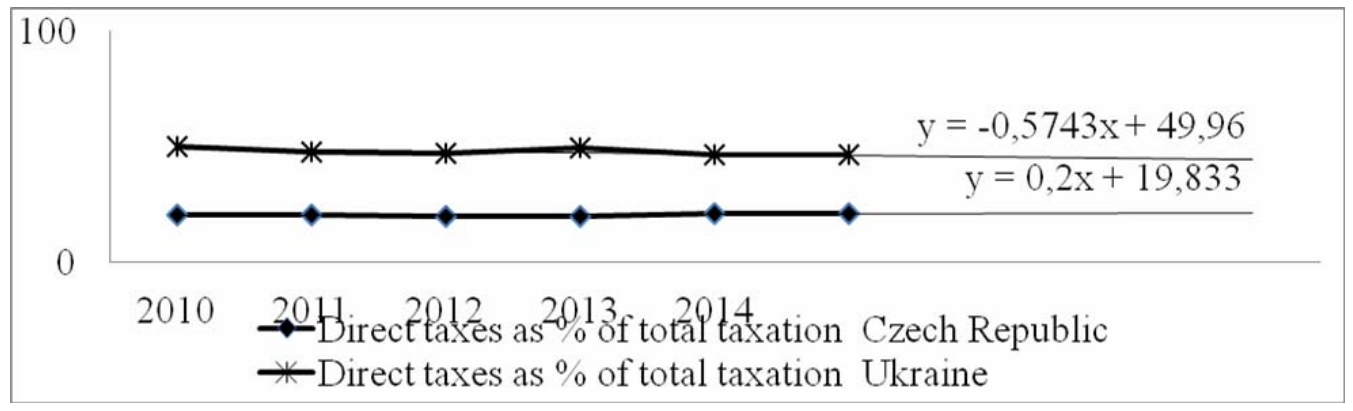

Figure 5. Direct taxes as \% of total taxation: the Czech Republic and Ukraine Source: compiled by the authors based on $[26,27,28]$

Taxes on income, profits, and capital gains are levied on the actual or presumptive net income of individuals, on the profits of corporations and enterprises, and on capital gains, whether realized or not, on land, securities, and other assets. Intragovernmental payments are eliminated by International Monetary Fund in consolidation [26, 29].

The Figure 6 demonstrates changes in the percentage of taxes on income, profits, and capital gains in total taxes for the Czech Republic and Ukraine from 2000 to 2014. This tax ratio shows the 
level of most significant direct tax in total amount of taxes. The Czech Republic and Ukraine have the highest rates of taxes on income, profits, and capital gains in 2007 and 2008. In 2009 the figures slumped enormously for both countries. However, the rates maintained the same level between 2011 and 2012. The lowest rates are found in 2014.

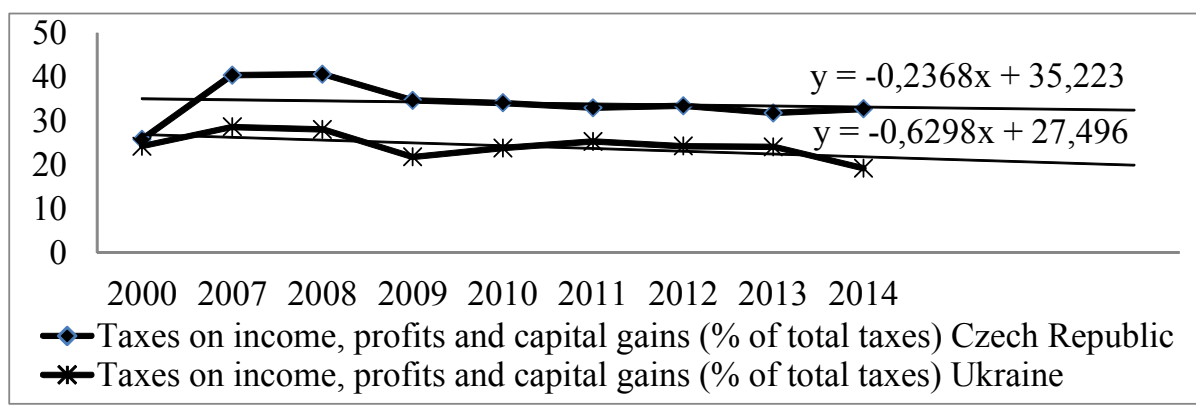

Figure 6. Taxes on income, profits, and capital gains ( $\%$ of total tax): the Czech Republic and Ukraine Source: compiled by the authors based on [29]

The graph (Figure 7) illustrates the main trends in the changes of correlation between total amount of direct taxes, corporate income tax and GDP for the Czech Republic and Ukraine between 2010 and 2016.

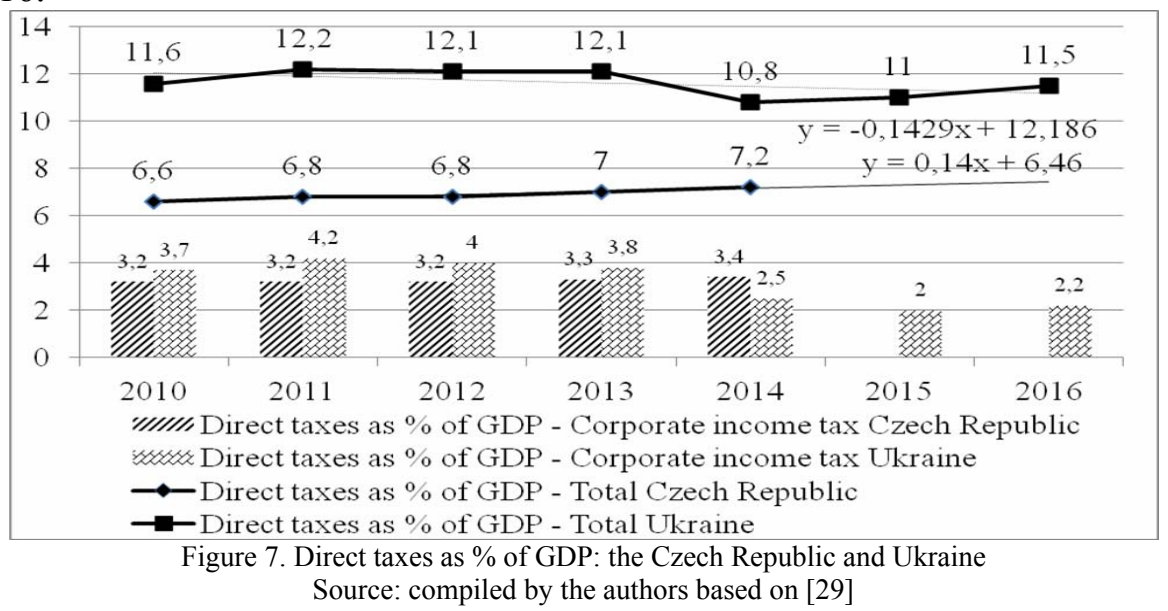

The most obvious trend in the graph is that indicators for the Czech Republic show lower ratios in most of the years and types of direct taxes in the graph. The second biggest trend in the graph is the significant decline of the indicator of corporate income tax to GDP for Ukraine from 4.2 in 2012 to 2.2 in 2016.

The line graph in Figure 8 gives information about the average annual correlation between taxes on income, profits, and capital gains and revenue for the Czech Republic and Ukraine from 2000 to 2014.

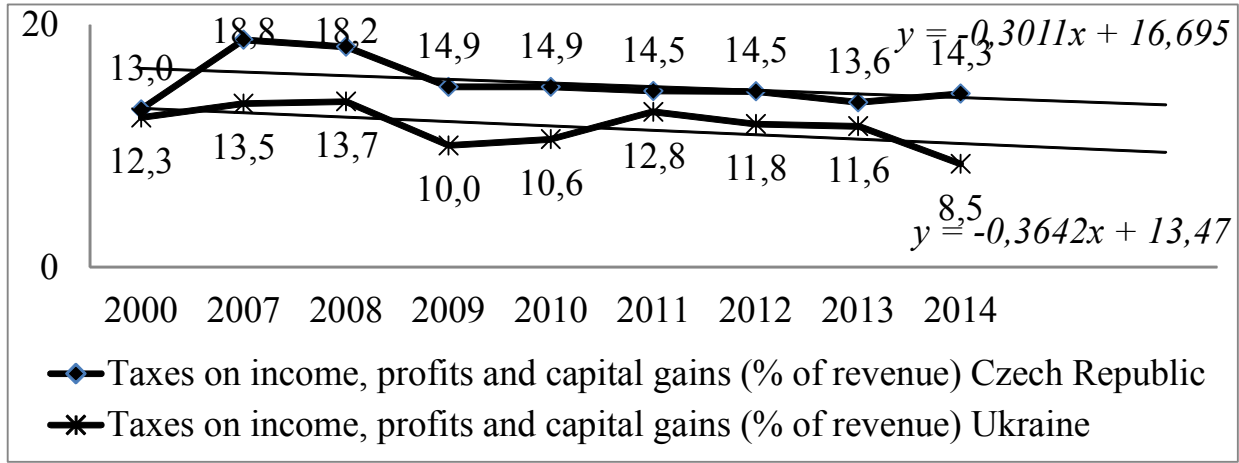

Figure 8. Taxes on income, profits, and capital gains as \% of revenue: the Czech Republic and Ukraine Source: compiled by the authors based on $[26,27,28]$ 
Although the indicator for the Czech Republic is slight lower, it echoes Ukrainian figures, increasing or declining at the same time. From 2007 onwards, there was a sudden decline in both countries. The Czech Republic figures plummeted to $14.90 \%$ in 2009 , a drop of $27 \%$. In the following five years, The Czech Republics' indicator was fluctuated around 14.5\% mark, while Ukrainian figures dipped to $10.0 \%$ in 2007 , and changed dramatically. In 2011, there was increased to $12.8 \%$, and reduced to $8.5 \%$ in 2016 .

The Figure 9 shows the fluctuation in profit tax as \% of commercial profit for the Czech Republic and Ukraine over the last four years.

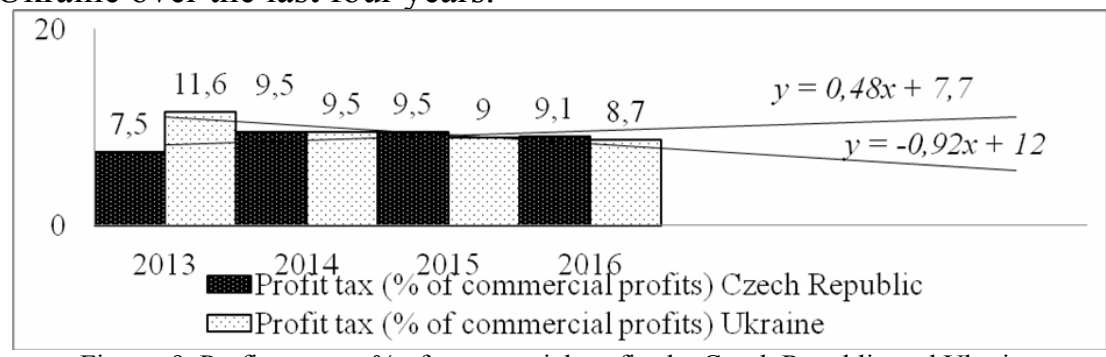

Figure 9. Profit taxes as \% of commercial profit: the Czech Republic and Ukraine Source: compiled by the authors based on $[26,27,28]$

From the graph it could be noted that each country has its own different trend, with very different characteristics. Ukrainian indicator does not have the range that the Czech Republic has. Its maximum level is $11.6 \%$ in 2013 , after which it drops gradually to about $8.7 \%$ in 2016 . In contrast to Ukraine, the Czech Republic has upward trend. Its indicator went up from $7.5 \%$ to $9.1 \%$ in 2016.

The table 2 gives information about external indicators in areas of direct taxes to measure similar individual ones for company and analyze common trends in direct taxation. The list of correlation between indicators for macroeconomic level and company could be found in this table too.

Table 2

Perfomance indicators for for management control of direct taxes: trends and correlation for the Czech Republic and Ukraine

\begin{tabular}{|l|l|l|l|}
\hline $\begin{array}{l}\text { External perfomance } \\
\text { indicators for direct } \\
\text { taxes }\end{array}$ & \multicolumn{2}{|c|}{ Trend } & $\begin{array}{c}\text { Internal perfomance } \\
\text { indicators for direct } \\
\text { taxes (for company) }\end{array}$ \\
\cline { 2 - 4 } & \multicolumn{2}{|c|}{ Ukraine } \\
\hline Non-financial performance indicators for direct taxes \\
\hline Tax payments & $\mathrm{y}=-0,5818 \mathrm{x}+12,8$ & $\mathrm{y}=-20,667 \mathrm{x}+191,87$ & Tax payments \\
\hline $\begin{array}{l}\text { Time to prepare and pay } \\
\text { taxes }\end{array}$ & $\mathrm{y}=-60,461 \mathrm{x}+725,13$ & $\mathrm{y}=-133,04 \mathrm{x}+1421$ & $\begin{array}{l}\text { Time to prepare and pay } \\
\text { taxes }\end{array}$ \\
\hline Financial performance indicators for direct taxes \\
\hline $\begin{array}{l}\text { Direct taxes as \% of } \\
\text { total taxation }\end{array}$ & $\mathrm{y}=0,2 \mathrm{x}+19,833$ & $\mathrm{y}=-0,5743 \mathrm{x}+49,96$ & $\begin{array}{l}\text { Direct taxes as \% of } \\
\text { total taxation }\end{array}$ \\
\hline $\begin{array}{l}\text { Taxes on income, } \\
\text { profits, and capital gains } \\
\text { (\% of total tax) }\end{array}$ & $\mathrm{y}=-0,2368 \mathrm{x}+35,223$ & $\mathrm{y}=-0,6298 \mathrm{x}+27,496$ & $\begin{array}{l}\text { Corporate income tax as } \\
\% \text { of total taxation }\end{array}$ \\
\hline $\begin{array}{l}\text { Direct taxes tax as \% of } \\
\text { GDP }\end{array}$ & $\mathrm{y}=0,14 \mathrm{x}+6,46$ & $\mathrm{y}=-0,1429 \mathrm{x}+12,186$ & $\begin{array}{l}\text { Direct taxes tax as \% of } \\
\text { Production }\end{array}$ \\
\hline $\begin{array}{l}\text { Corporate income tax as } \\
\% \text { of GDP }\end{array}$ & $\mathrm{y}=0,05 \mathrm{x}+3,11$ & $\mathrm{y}=-0,3714 \mathrm{x}+4,6857$ & $\begin{array}{l}\text { Corporate income tax as } \\
\% \text { of Production }\end{array}$ \\
\hline $\begin{array}{l}\text { Taxes on income, } \\
\text { profits, and capital gains } \\
\text { as \% of revenue }\end{array}$ & $\mathrm{y}=-0,3011 \mathrm{x}+16,695$ & $\mathrm{y}=-0,3642 \mathrm{x}+13,47$ & $\begin{array}{l}\text { Corporate income tax as } \\
\text { \% of Revenue (Sales) }\end{array}$ \\
\hline $\begin{array}{l}\text { Profit taxes as \% of } \\
\text { commercial profit }\end{array}$ & $\mathrm{y}=0,48 \mathrm{x}+7,7$ & $\mathrm{y}=-0,92 \mathrm{x}+12$ & $\begin{array}{l}\text { Corporate income tax as } \\
\% \text { of Gross profit }\end{array}$ \\
\hline
\end{tabular}


In the internal aspect of performance measurement of direct taxes for organization it is necessary to evaluate individual trend for each company and compare with common trend for country.

Conclusions. Performance measurement of direct taxes must include various techniques to provide quantitative analysis within management control of direct taxes context. Time series (histogram), correlation-regression analysis, extrapolation, methods of data collection could provide comprehensive research and corresponding results to make decisions in direct taxation for companies.

The data assessment has been provided in the over last ten years, it means in period from the year 2007 to 2016. The number of tax payments has decreased in both of the countries. One of the very interesting aspects is that time to prepare and pay taxes have declined since the peak in 2007. The biggest decrease in the Czech Republic is between 2008 and 2009. The drop also reflect the change of legislative in personal income tax that lots of small entrepreneurs save time being allowed to calculate their expenditure as a lump sum deduction from the gross income. Nevertheless, the biggest drop in the Ukraine is displayed between 2007 and 2008.

The share of direct taxes in total amount of taxes is decreasing in Ukraine while it maintains the common trend in the Czech Republic. In contrast to Ukraine, the Czech Republic has the growing trend. Overall, a companies could use these results to compare with own figures and estimate common correlations in country, industry as well as companies correlation with revenue.

In addition, more detailed communications should be determined as well. This implies a change in the structure of revenues and expenses affecting the change in the size of direct taxes for each year. The results of the analysis could be appreciable for the purpose of the companies, nevertheless each company should take into the account own special conditions.

\section{Лiтература}

1. Musgrave, B. P. Tax Policy in the Global Economy [Text] // Cheltenham : Edward Elgar Publishing Limited. - 2002. 488 p.

2. Ulbrich, H. H. Public Finance in Theory and Practice [Text] // New York : Routledge. - 2011. - 432 p.

3. Dyreng, S. D. Public pressure and corporate tax behavior [Text] / S. D. Dyreng, J. L. Hoopes, J. H. Wilde // Journal of Accounting Research. - 2016. - Vol. 54. - № 1. - P. 147-186.

4. Hansen, B. The economics theory of fiscal policy [Text] / B. Hansen ; Translated P. E. Burke. - London : Routledge. 2003. -381 p.

5. Armstrong, C. S. Corporate governance, incentives, and tax avoidance [Text] / C. S. Armstrong, J. L. Blouin, A. D. Jagolinzer, D. F. Larcker // Journal of Accounting and Economics. - 2015. - № 60 (1). - P. 1-17.

6. Graham, J. R. Incentives for tax planning and avoidance: Evidence from the field [Text] / J. R. Graham, M. Hanlon, T. Shevlin, N. Shroff // The Accounting Review. - 2013. - № 89 (3) - P. 991-1023.

7. Minnick, K. Do corporate governance characteristics influence tax management [Text] / K. Minnick, T. Noga // Journal of corporate finance. - № 16 (5). - 2010. - P. 703-718.

8. Lisowsky, P. Do publicly disclosed tax reserves tell us about privately disclosed tax shelter activity [Text] / P. Lisowsky, L. Robinson, A. Schmidt // Journal of Accounting Research. - 2013. - № 51 (3). - P. 583-629.

9. Trabandt, M. Fiscal Policy after the Financial Crisis [Text] / M. Trabandt, H. Uhlig // Chicago : University of Chicago Press. $-2013 .-704 \mathrm{p}$.

10. Zimmerman, J. L. Taxes and firm size [Text] // Journal of accounting and economics. - 1983. - Vol. 5. - P. 119-149.

11. Rego, S. O. Equity risk incentives and corporate tax aggressiveness [Text] / S.O. Rego, R. Wilson // Journal of Accounting Research. - 2012 - № 50 (3). - P. 775-810.

12. Krajňák, M. Analysis of the Dependence of Corporate Tax in Relation to the Tax Depreciation of Fixed Tangible Assets

[Text] / M. Krajňák, R. Stř́lková, J. Široký // Theoretical And Practical Aspects of Public Finance. - Prague : University of Economics. - 2016. - P. 29-33.

13. Đorđević, M. Analysis of performance to direct taxes in the tax system of the Republic of Serbia [Text] / M. Đorđević // Facta Universitatis. Economics and Organization. - 2015. - № 12 (1). - P. 55-68.

14. Christensen, D. M. Top management conservatism and corporate risk strategies: Evidence from managers' personal political orientation and corporate tax avoidance [Text] / D. M. Christensen, D. S. Dhaliwal, S. Boivie, S. D. Graffin // Strategic Management Journal. - 2015. - № 36 (12). - P. 1918 - 1938.

15. Speklé, R. F. The use of performance measurement systems in the public sector: Effects on performance [Text] / R. F. Speklé, F. H. Verbeeten // Management Accounting Research. - 2014. - № 25 (2). - P. 131-146.

16. Robinson, J. R. Performance measurement of corporate tax departments [Text] / J. R. Robinson, S. A. Sikes, C. D. Weaver // Accounting Review. - 2010. - № 85 (3). - P. 1035 - 1064.

17. Tyteca, D. Linear programming models for the measurement of environmental performance of firms - concepts and empirical results [Text] / D. Tyteca // Journal of productivity analysis. - 1997. - № 8 (2). - P. 183-197.

18. Horan, S. M. After-tax performance measurement [Text] / S. M. Horan, P. N. Lawton, R. R. Johnson // The Journal of Wealth Management. - 2008. - № 11 (1). - P. 69 - 83.

19. Musgrave, R. Public Finance in Theory and Practice [Text] / R. Musgrave, P. Musgrave. - New York : McGraw-Hill. 1989. $-627 \mathrm{p}$.

20. McGuire, S. T. Dual class ownership and tax avoidance [Text] / S. T. McGuire, D. Wang, R. J. Wilson // The Accounting Review. - 2014. - № 89 (4). - P. 1487 - 1516.

21. Cheng, C. A. The effect of hedge fund activism on corporate tax avoidance [Text] / C. A. Cheng, H. H. Huang, J. 
Stanfield // The Accounting Review. - 2012. - № 87 (5). - P. 1493 - 1526.

22. Badertscher, B. A. The separation of ownership and control and corporate tax avoidance [Text] / B. A. Badertscher, S. P.

Katz, S. O. Rego // Journal of Accounting and Economics. - 2013. - № 56 (2). - P. 228-250.

23. DeBacker, J. Importing corruption culture from overseas: Evidence from corporate tax evasion in the United States [Text] / J. DeBacker, B. T. Heim, A. Tran // Journal of Financial Economics. - 2015. - № 117 (1). - P. 122-138.

24. Guenther, D. A. Earnings management in response to corporate tax rate changes: Evidence from the 1986 Tax Reform Act [Text] // Accounting Review. - 1994. - Vol. 69, № 1. - P. 230 - 243.

25. Doing Business [Electronic resource] // The World Bank. - Available at: http://www.doingbusiness.org/

26. DG Taxation and Customs Union, based on Eurostat data [Electronic resource]. - Available at: http://ec.europa.eu/taxation_customs/business/economic-analysis-taxation/data-taxation_en.

27. State Treasury Service of Ukraine [Electronic - resource]. - Available at: http://www.treasury.gov.ua/main/uk/publish/category?cat id=23608\&page=2.

28. Tax Recovery mechanisms of social and economic development in the context of the reform of 2016 [Electronic resource]. - Available at: http://www.niss.gov.ua/articles/2299/

29. International Monetary Fund Country Information [Electronic resource]. - Available at: http://www.imf.org/external/country/index.htm\#C.

Стаття надійила до редакиїі 17.02.2017

(C) Кузнецова С., Кржикаллова К., Кузнецчов А.

\section{References}

1. Musgrave, B. P. (2002). Tax Policy in the Global Economy. Cheltenham: Edward Elgar Publishing Limited.

2. Ulbrich, H. H. (2011). Public Finance in Theory and Practice. New York: Routledge.

3. Dyreng, S. D., Hoopes, J. L., \& Wilde, J. H. (2016). Public pressure and corporate tax behavior. Journal of Accounting Research, 54(1), 147-86.

4. Hansen, B. (2003). The economics theory of fiscal policy. London: Routledge.

5. Armstrong, C. S., Blouin, J. L., Jagolinzer, A. D., \& Larcker, D. F. (2015). Corporate governance, incentives, and tax avoidance. Journal of Accounting and Economics, 60(1), 1-17.

6. Graham, J. R., Hanlon, M., Shevlin, T., \& Shroff, N. (2013). Incentives for tax planning and avoidance: Evidence from the field. The Accounting Review, 89(3), 991-1023.

7. Minnick, K., \& Noga, T. (2010). Do corporate governance characteristics influence tax management?. Journal of corporate finance, 16(5), 703-718.

8. Lisowsky, P., Robinson, L., \& Schmidt, A. (2013). Do publicly disclosed tax reserves tell us about privately disclosed tax shelter activity? Journal of Accounting Research, 51(3), 583-629.

9. Trabandt, M., \& Uhlig, H. (2013). Fiscal Policy after the Financial Crisis. Chicago: University of Chicago Press.

10. Zimmerman, J. L. (1983). Taxes and firm size. Journal of accounting and economics, 5, 119-149.

11. Rego, S. O., \& Wilson, R. (2012). Equity risk incentives and corporate tax aggressiveness. Journal of Accounting Research, 50(3), 775-810.

12. Krajň́k, M., Stř́lková, R., \& Široký, J. (2016). Analysis of the Dependence of Corporate Tax in Relation to the Tax Depreciation of Fixed Tangible Assets. Theoretical And Practical Aspects of Public Finance, 29-33. Prague: University of Economics.

13. Đorđević, M. (2015). Analysis of performance to direct taxes in the tax system of the Republic of Serbia. Facta Universitatis. Economics and Organization, 12(1), 55-68.

14. Christensen, D. M., Dhaliwal, D. S., Boivie, S., \& Graffin, S. D. (2015). Top management conservatism and corporate risk strategies: Evidence from managers' personal political orientation and corporate tax avoidance. Strategic Management Journal, 36(12), 1918-1938.

15. Speklé, R. F., \& Verbeeten, F. H. (2014). The use of performance measurement systems in the public sector: Effects on performance. Management Accounting Research, 25(2), 131-146.

16. Robinson, J. R., Sikes, S. A., \& Weaver, C. D. (2010). Performance measurement of corporate tax departments. The Accounting Review, 85(3), 1035-1064.

17. Tyteca, D. (1997). Linear programming models for the measurement of environmental performance of firms - concepts and empirical results. Journal of productivity analysis, 8(2), 183-197.

18. Horan, S. M., Lawton, P. N., \& Johnson, R. R. (2008). After-tax performance measurement. The Journal of Wealth Management, 11(1), 69-83.

19. Musgrave, R., \& Musgrave, P. (1989). Public Finance in Theory and Practice. New York: McGraw-Hill.

20. McGuire, S. T., Wang, D., \& Wilson, R. J. (2014). Dual class ownership and tax avoidance. The Accounting Review, $89(4), 1487-1516$

21. Cheng, C. A., Huang, H. H., \& Stanfield, J. (2012). The effect of hedge fund activism on corporate tax avoidance. The Accounting Review, 87(5), 1493-1526.

22. Badertscher, B. A., Katz, S. P., \& Rego, S. O. (2013). The separation of ownership and control and corporate tax avoidance. Journal of Accounting and Economics, 56(2), 228-250.

23. DeBacker, J., Heim, B. T., \& Tran, A. (2015). Importing corruption culture from overseas: Evidence from corporate tax evasion in the United States. Journal of Financial Economics, 117(1), 122-138.

24. Guenther, D. A. (1994). Earnings management in response to corporate tax rate changes: Evidence from the 1986 Tax Reform Act. Accounting Review, 69(1), 230-243.

25. Doing Business. The World Bank. Available at: http://www.doingbusiness.org

26. DG Taxation and Customs Union, based on Eurostat data. Available at: http://ec.europa.eu/taxation_customs/business/economic-analysis-taxation/data-taxation_en.

27. State Treasury Service of Ukraine. Available http://www.treasury.gov.ua/main/uk/publish/category?cat id=23608\&page=2.

28. Tax Recovery mechanisms of social and economic development in the context of the reform of 2016. Available at: http:/www.niss.gov.ua/articles/2299/

29. International Monetary Fund Country Information. Available at: http://www.imf.org/external/country/index.htm\#C Received 17.02.2017

(C) Kuznetsova S., Krzikallová K., Kuznetsov A. 